AL IBTIDA: JURNAL PENDIDIKAN GURU MI (2020) Vol 7 (1) : 100-116

DOI: http://dx.doi.org/ 10.24235/al.ibtida.snj.v7i1.6322

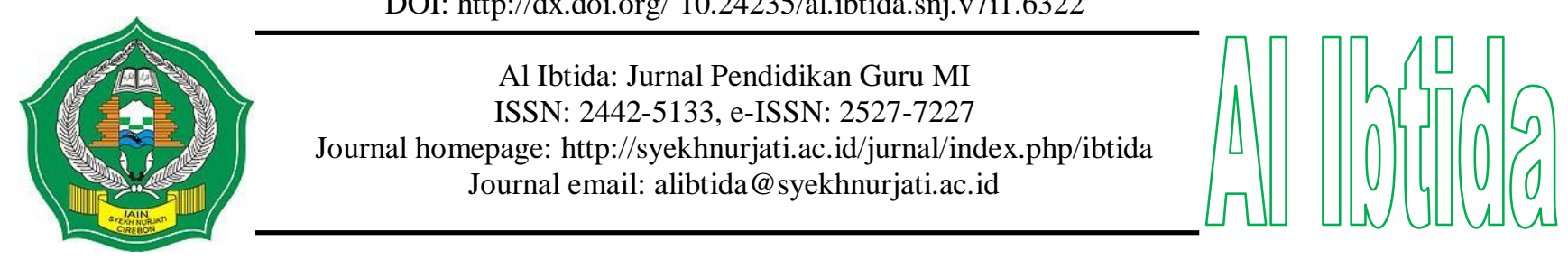

\title{
Managing School Culture on Excellent Elementary School in East Java Indonesia
}

\author{
Muhammad Walid* \\ *Department of Madrasah Ibtidaiyah Teacher Education, Faculty of Tarbiyah and Teacher Training, \\ UIN Maulana Malik Ibrahim Malang, Indonesia \\ Email: walidpgmi@pgmi.uin-malang.ac.id \\ Lutfiya Qomaril Uyun** \\ ***Department of Madrasah Ibtidaiyah Teacher Education, Faculty of Tarbiyah and Teacher Training, \\ UIN Maulana Malik Ibrahim Malang, Indonesia \\ Email: lutfiyaqomariluyun@gmail.com
}

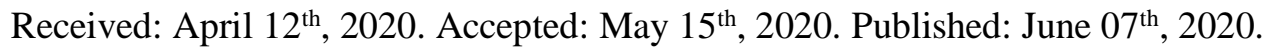

\begin{abstract}
This research aims to find out how a school culture in an Excellent School in East Java is managed so that it can shape students' characters. This study is descriptivequalitative approach. The data collection performed through observation, interview, and documentation. The data analysis is conducted by reducing irrelevant data, presenting data and drawing a conclusion. In anlyzing the data validity, researcher used a credibility test by using data triangulation and member check. The research findings indicate that the excellent school culture management process in East Java has several steps such as planning, organizing, implementation, and evaluation. The strategies in developing the school culture are school's routine activity/habituating, spontaneous activity/habituating, modeling and conditioning. The strategies are applied through modeling, teaching, and reinforcing. It implies that the principal of school play a strong role in student character education.
\end{abstract}

Keywords: management, school culture, excellent school.

\begin{abstract}
Abstrak
Penelitian ini bertujuan untuk mengetahui bagaimana sebuah budaya sekolah pada sekolah unggulan di Jawa Timur dikelola sehingga dapat membentuk karakter siswa. Penelitian ini adalah penelitian kualitatif deskriptif. Data dikumpulkan melalui observasi, wawancara, dan dokumentasi, sedang analisis data dilakukan dengan mereduksi, memaparkan dan menyimpulkan. Untuk keabsahan data diuji dengan uji kredibilitas; triangulasi data, dan member check. Hasil penelitian menunjukkan bahwa proses pengelolaan budaya sekolah unggulan di Jawa Timur memiliki beberapa tahapan, yaitu perencanaan, pengorganisasian, pelaksanaan, dan pengevaluasian. Strategi pengembangan budaya sekolah pada sekolah unggulan diantaranya dilakukan dengan kegiatan rutin di sekolah, aktivitas spontan, keteladanan, dan pengkondisian. Adapun strategi pelaksanaannya menggunakan pemodelan (modeling), pengajaran (teaching), dan penguatan lingkungan (reinforcing). Implikasi dari temuan ini adalah bahwa pengelola sekolah memainkan peranan yang sangat penting dalam pembentukan karakter siswa.
\end{abstract}

Kata kunci: pengelolaan, budaya sekolah, sekolah unggulan. 


\section{INTRODUCTION}

Education cannot be separated from culture. The educational process is a habituating process, and vice versa. Similarly, one of the strategies applied during the process of shaping children's characters is habituating process in the school environment or through the school culture. All organizations have culture, but school culture has more essential meanings. Because, school culture has important role in developing the students' character building (Samong, Suryadi, \& Budimansyah, 2016). Deal \& Peterson (2016) claimed that the educational world faces various challenges of change and complex objectives. Thus, culture takes a more vital role than the economic world.

School culture is a filter of values and norms brought from outside the school (Mac Neil, Prater, \& Busch, 2009; Zamroni, 2007), and culture will determine how pedagogy will be applied (Kurniawan et al., 2019), how the assessment will be performed, and how the relationship between teacher and the colleagues is. If the school has a positive and strong culture, then hopes, activities and schools' program will run well. Likewise, when the school culture is positive and strong, then the school members, such as the school principal, teachers and students will be able to solve various arisen problems using certain ways that have been proven successful because culture is considered as "the way things are done here". School culture guides all the school members on how they should behave.

The main duties of the school principal are developing and preserving the school culture so that it always runs well. A good school principal is a developer of school culture who has a basic pattern of assumption, a system of values of faith and habits as well as various forms of school products. It will encourage all the school members to be cooperative, based on trust, trigger all school's members' participation, initiate new ideas to occur, and provide a chance for any changes in school as they will lay down on the principle of "why not the best"? (Zamroni, 2016). Hackman \& Wageman (2007) suggest that different leaders can behave in their own unique ways and will achieve effective leadership outcomes. Thus, school culture will be able to shape students' character in that school.

In line with that, organizational experts say that paying attention to culture is the most important action for the leader to perform and the principal roles' impact on learning is mediated through the school culture and it is not a direct effect (Hallinger \& Heck 1998). Watson (2001) warned us that if the culture is not hospitable to learning then student achievement can suffer. Fink \& Resnick (2001) reminded us that school principals are responsible for establishing a pervasive culture of teaching and learning in each school. Therefore, there is a very positive relationship between the health of school organizations and 
the process of creating school culture. A good school condition will support the growth of a good school culture. Likewise, an unhealthy school condition will hamper the growth of school culture (MacNeil et al., 2009). Involving creativity in school culture is the leader's responsibility and its implementation demands all school's members' responsibility (Godfrey, 2016). A leader should understand and recognize the strategies and ways of shaping school culture.

One of the roles of a good school culture is shaping a student character. In other words, character education can be integrated and developed through good school culture. Shaping students' character can also be conducted by managing a good school culture, and it can be implemented since children's early education level at school. As the organizer, the role of school in managing character education is expected to be a medium to carry out the mission of character education (Hidayatullah, 2010). Mirshekari \& Ghasemi (2019) stated that a nation must create rules in determining the rights and wrongs, the things that are allowed or not allowed to do, the justice and injustice as well as the proper and improper. The importance of character is formed in schools through culture based education. Culture-based education management pattern plays an important role in creating quality and human potential. The management of culture-based character education needs the rule from the beginning because character education regulates all the positive things that are done by educators and their effect on the participants character they teach (Ash-shidiqqi, 2018).

Management of character education through culture is an effort to educate students to have a good understanding so that they can behave in accordance with applicable norms. The management of character education through culture is expected to produce people who can make decisions and are responsible for each decision taken (Agboola \& Tsai, 2012). The management of character education through culture is expected that students can resolve conflicts and be able to socialize with good morals. They can try to solve the problems they face following to the values of daily life. It is because of student's needs to understand their personalities and their environment (Benninga et al., 2003; Suryani et al., 2020). Character education is both a rooted and developing discipline (Amini, Yurnita, \& Hasnidar, 2017; Billig, Jesse, \& Grimley, 2008). Even though there is no consensual definition, it can be widely described as a school based process to promote personal development in youth, through the development of virtue, moral values, and moral agency (Pattaro, 2016). In the context of schooling, the management of character education through school culture aims to build the character of students so that they have a strong national character, such as honesty, responsibility, high work ethics, having faith, and high piety so that they become dignified. 
School or Madrasah cannot be separated from any situation caused by the changes. School must responsible to educate the students so that they can adjust themselves in society and solve any matter they face. Thus, shaping students' character in Elementary or Islamic Elementary School must be fully designed. Character building can be formed through good school culture in schools. School culture must always be managed and developed so that the formation of student character can work well. Therefore, the existence of a good school (character) cannot be separated from how to manage its school culture properly. Therefore, this paper also wants to see how the management of school culture in primary schools in East Java Indonesia in shaping the character of students so that they become good.

This study was conducted in an excellent and high achiever school in East Java, Indonesia. Elementary School (SD) or Islamic Elementary School (MI) is the first phase to shape a good character of the children, which is hoped it will develop into good habits when they grow up so that they will become strong human beings who are closer to perfection (Wiyani, 2013). The flagship primary school under study also sought to create a good school culture in producing a generation of the nation that was not only intelligent but also have a good character. Character has a very important value; children who master in knowledge also in maintaining a good character (Shumer, Lam, \& Laabs, 2012). This excellent elementary school also has brilliant achievements not only from the students, but also the educators and the school culture. The Achievement is not only at the regional level, but also at national, even international level. Students have intellectual intelligent and the character of al-karimah (good character).

As far as the research of researchers on previous studies, was found several studies related to school culture and character building, including the research of Supraptiningrum \& Agustini (2015) that focus on the activities carried out in shaping student character; Fauzia (2015); Wardani (2014) focus on activities that support the formation of character and its implementation strategies. Syarifah (2015) studied about the relationship between school culture and character formation. Tłuściak-Deliowska, Dernowska \& Gruenert (2017) researching about how school achievements interplay with school culture and principal behaviors. Meanwhile, Redding \& Corbett's research (2018) focused on how to move a school culture from a negative to a positive. The research results are there are three key practices for rapid improvement, namely build a strong community intensely focused on student learning, solicit and act upon stakeholder input, and engage students and families in pursuing education. 
Difference from the previous studies, this study was conducted qualitatively and aims to find out the principals' practices in managing character education through school culture. The character education managed by the principal in the school starting from the planning, implementation and evaluation are became the research objectives. The school culture management is the effort to develop the best school culture or certain pattern concept (example, reference, types, etc), which can represent an object that is made to produce something. It is the way in developing school culture to make it better and improve the school's quality. Thus, school culture development can be used as a reference and knowledge about how to develop a good school culture. In other words, the school culture management or development is the school's determination concerning how students' characters can be shaped through the existing school culture in executing and implementing the desired character education. Therefore, this paper would like to convey how the process of managing school culture takes place in shaping the character of students, especially facing this millineal era and how the management strategy.

\section{METHODS}

This study was conducted at Sekolah Dasar Plus Rahmat Kediri City, East Java Province that has a good Islamic school culture for shaping students' characters. This elementary school also has other exceptional factors which makes it not only able to create a universal culture but also an Islamic atmosphere. This school also serves a full day school learning system. It has a school culture development unit to help to shape students' character. Sekolah Dasar Plus Rahmat in Kediri City been granted Widya Pekerti Nugraha Provinsi Jawa Timur, a prestigious award for character education. This elementary school achieved a good reputation for both academic and non-academic aspects in every year.

Therefore, this study seeks to know the management process of school culture in shaping students' characters at Sekolah Dasar Plus Rahmat, an excellent school in East Java, by using a qualitative descriptive approach (Sugiyono, 2013). The techniques of data collection are depth interview, observation, and documentation. The interview was conducted through structured and unstructured interviews. The informants are the School Principal, Vice School Principal, Coordinator of Curriculum Affairs, Coordinator of Students Affairs, Coordinator of Public Relation Affairs and other school members who know the research theme.

Moreover, the natures of research object are human behavior and attitude, natural phenomenon, working process and the use of respondents on a small scale. Accordingly, the writer used observation for collecting the data. Meanwhile, documentation was employed to 
record all the needed things to support the writing. The data analysis was performed through data reduction, data presentation, and drawing conclusion. For checking the data validity, the writer used credibility test through data triangulation and member check (Arikunto, 2006).

\section{RESULTS AND DISCUSSION}

Management of character education is emphasized in the 2013 curriculum. In this 2013 curriculum students need to know the authority of the character which will be used as a source of assessment of learning outcomes, so that students can prepare themselves through mastery of certain characters (Agung, 2011). Management of a good school culture required the activities; planning, organizing, implementing, and evaluating. The core leader in planning, organizing, implementing, and evaluating lies with the principal and vice-principal. Then the principal outlined and organized the school's core team of 6 school sector coordinators. Then, each sector also has a special planning, organizing, implementing, and evaluating in each fields.

The stages of managing the development of school culture, including (1) conducting planning, before entering the start of new teachings, the core school team consisting of school principals, deputy principals, school sector coordinators plan to formulate the program for the next 1 year and evaluate the previous program and school culture; (2) next, the principal explained the programs and culture he wanted to create for the next year to the foundation; (3) holding a workshop or working meeting together with school residents. At the workshop there were also participants from the department and others to explain the programs and culture of the school. It is a result of approval from the foundation that was socialized to all school residents; (4) organizing programs, each field coordinator and organizational structure regulate how the programs and culture are arranged in such a way before they are realized or continued at the implementation stage; (5) carry out planned programs. Thus, all school components must play a role in the existing school culture; (6) evaluating existing programs. In this evaluation phase, there are daily evaluations, weekly evaluations, monthly evaluations, and annual evaluations. There are also direct evaluations and indirect evaluations as well as evaluations at the time that do have to be evaluated. The main tasks and functions of the school core team are presented in the following table 1.

Table 1. Management of School Culture Development in Forming Student Character

\begin{tabular}{l}
\hline \multicolumn{2}{c}{ Meveloper } \\
$\begin{array}{l}\text { Principal and a. Identify the problems that arise, by identifying the conditions } \\
\text { Deputy Principal } \\
\text { existing in the school. }\end{array}$ \\
b. Planning the programs to develop school culture together with the \\
core team at annual meetings.
\end{tabular}


c. After planning, the principal presented to the founder and the committee that good school had a planned program. Then, the founder provides input. Furthermore, from that, it socialized in work meetings to all teachers and founders, and all present.

d. Organizing programs before they are implemented.

e. Carry out programs that have been planned. At the implementation stage, it is expected that the school community will have to carry out as well as possible.

f. Monitoring during the program to control the programs implemented.

g. Evaluate existing programs through short-term, medium-term, and long-term evaluations.

Student Affairs a. Planning an annual program of students.

Coordinator b. Organizing by collaborating with various parties involved in the school, namely the principal, vice principal, public relations coordinator, psychology staff, counseling staff, \& all teachers.

c. Implementing the programs and work together with psychology officers and counselors to form disciplinary enforcement teams and conduct good projects.

d. Evaluate programs that are carried out. Performed in coordination verbally / in writing with psychology / and Principal as decision maker.

Coordinator of a. Planning from the coordinator and principal meetings, which we Public Relations previously evaluated in the previous program.

b. Furthermore organized until the level.

c. The implementation is adjusted to the curriculum schedule; the implementation is in collaboration with student guardians and all school components.

d. Evaluation through questionnaire and proposals from others. There are temporary evaluations, special evaluations, and outreach evaluations.

Curriculum a. Planning at the initial learning meeting with the school core team.

Cordinator b. Subsequently, it was taken to the foundation, and then the stage of socialization to teachers to the guardians of students and students.

c. Implemented in accordance with the 2013 curriculum.

d. Evaluated.

Coordinator of a. Planning a program.

Faith and Taqwa b. Carry out the planned program.

c. Organized by making each person in charge of each program.

d. Control the programs implemented.

e. Evaluate the program.

Competition a. Planning before the start of new learning in a meeting with the core Coordinator team.

b. The Coordinator competition, the Vice coordinator competition, and the 10 members of the Coordinator competition then planned on the realm of the race.

c. Next, carried out. The Coordinator competition also held coaching for participants who took part in the competition.

d. Controlling through social media.

e. For every month at the 3rd week the competition team also routinely conducts evaluation activities both meetings and via whats 
app groups.

\begin{tabular}{|c|c|}
\hline $\begin{array}{l}\text { Facility and } \\
\text { Infrastructure } \\
\text { Coordinator }\end{array}$ & $\begin{array}{l}\text { a. Planning work by making programs and procuring inventory that is } \\
\text { not yet in schools. } \\
\text { b. Furthermore, it is socialized and organized by making a submission } \\
\text { report to the school principal as a source of funding. } \\
\text { c. Carrying out the program was assisted by Cleaning Service (CS). } \\
\text { d. The Facility and Infrastructure Coordinator team and the CS team } \\
\text { worked together to monitor the facilities at the school. } \\
\text { e. Conduct an evaluation, there are short term, medium term, long } \\
\text { term. }\end{array}$ \\
\hline
\end{tabular}

Based on table 1 above, it can be seen that each school core team member has different duties and functions according to their respective fields. However, in carrying out their duties and functions, each team member always coordinates with the principal as the team leader. This is done so that the vision and mission of the school can be achieved, namely managing a good school culture. It will have an impact on improving the character of students.

\section{The Management of Excellent Elementary School Development}

School is an educational organization led by a school principal. School principal holds a higher position in organizing, managing and directing the teachers and all school components to make the best school's quality. Without any effort, hard work and critics towards the current educational situation will not be developed and dynamic, there will be no improvement, and school will experience boringness. Regarding to this, school principal and educators are required to always be informed with the globalization era, which is always developing, along with the innovations that make the school becomes excellent. They creates qualified generations of the nation who also have good morals or akhlaq. School culture has already become the school's authority and responsibility, so it is more intensive and extensive (Andang, 2014).

Shaping school cultural should be a national movement for creating schools that foster ethical, responsible and caring young people by modeling and teaching good character through emphasis on universal values that we all share. It is the intentional, proactive effort by schools to instil in their students important core ethical values such as caring, honesty, fairness, responsibility and respect for self and others. In line with this, Deal \& Peterson (2016) asserted that the educational world has faced various challenges in changes and complex goals; hence, culture takes a more importsnt role than the economic world. School culture provides a framework for decision and attitude making (Zamroni, 2016). If a school has a positive and strong culture, then hopes, activities and program execution will run well. 
Character education that focuses on developing students' identity to be smart and have the character needed to face the demands of the times (Agung, 2011).

School culture guides the school's members about how to behave. Students who have good character or high emotional intelligence will be protected from any problems that generally occurred (Nurhayati, 2018). The main duties of a school principal are developing and preserving school culture, so it will always run well (Zamroni, 2016). School culture must always be developed and innovated to become better to shape students' character. The observed excellent school culture is already well-organized, and the school always maintains and manages the existing school culture so that the students will get a good achievement and good character (Sobri, 2010).

A good school is a dynamic one, which always develops along with the development era and does not change the school's special characteristics. Thus, the school must always be responsive to the current condition. School must always be innovative to create a good school condition since a good environment can affect the formation of students' good character. The development of school culture is necessary for shaping students' characters at school (Uliana, 2013).

As known, the character education policy is inseparable from the various problems and challenges faced by the Indonesian people. The educational policy affects the learning model of national character values in schools (Saidek \& Islami, 2016). Learning models about characters must be changed from time to time and carried out to the process of sustainable innovation. School has a certain model in developing school culture through which this excellent elementary school wants to create a school culture that is in accordance with the school's vision and mission. It also seeks to guide students to be religious, have akhlaq, are excellent in both academic and non-academic aspects, and master in science and technology, which are in accordance with Quran, Hadith, and Ijtihad (Islamic independent reasoning for performing certain activities). The school's mottos are strengthening intention, execute the mandate, pursue achievement, and reach out to get God's blessing.

This is in line with the literature that in order to make schools implement character education based on local cultural wisdom, there is a need to ask a number of questions about the background of the school and the motto, where the motto is the values that must be implemented by the principal, then formulated into a new vision that should implemented by all school educators in accordance with the demands of the times, and then disseminated to all stakeholders.. The new visions which are based on the core values (the values of local wisdom) will be formulated positively, easily understood, communicated in socialization 
activities. At the end, it would be the most superior visions containing the local wisdom values that will be followed by school's citizen (Sulasmono, Ekosiswoyo, \& Widodo, 2017).

This excellent elementary school tries to always create an Islamic school culture based on the school's vision and mission to shape and develop the good students' and all school members' character. Not only the students' character but all school components or school's members' character is crucial to be shaped. This school wishes to develop an institution that has good quality and to shape students' character. It wants to deliver a preach as a response to the current condition of the nation, a moral degradation (Harahap, Hasyimsyah, \& Suwardi, 2017). Thus, conveying Islamic preaches becomes one of the school's intentions. Educators should not eliminate the identity of Indonesian citizens who possess good morals (Mahbubi, 2012).

The school culture development also needs changes for betterment as adjusted to the school's vision and mission. It is in line with Lewin's three steps model, which explain the strategy to change a certain condition or school culture named unfreezing, change and refreezing. The condition changes are implemented systematically, directed, and creates fewer problems (Lewin, 1951). School also needs innovations in developing school culture. It conducts school visits to good reputable schools; afterward, certain adjustments are made based on the school's condition. This school also always tries to upgrade the educators' and staff's expertise. The school vision is absolute. This school has also conducted a questioner assessment regarding the school's matters by delivering the questioners to the teachers, students, and parents. Improvement is always performed to create a positive school culture.

This elementary school develops school culture by creating innovations to run the school's vision and mission successfully. It runs through visiting other schools and knowledge upgrade obtained from other sources so that school culture will always be conducive and positive. The school's worthy experiences will then be adopted and set as the school culture development model. The positive school culture will develop and change all schools' members' attitudes reflecting a more efficient and effective attitude to reach achievements. In addition, through a school culture such as social and forms of learning services that involve the community can increase civic engagement, social responsibility, and academic achievement (see for example Stott \& Jackson, 2005; Billing \& Jesse, 2008). A change of school culture is fundamental and must be implemented through full awareness and tryouts that require a lengthy process, so it needs consistency (Zamroni, 2016). This is in line with Pala's findings literature, that the development of culture in order to shape character requires a long time (Pala, 2011). 


\section{Strategies for Implementing School Culture in Excellent Elementary Schools}

Given the importance of character education, many parties are demanding an increase in the intensity and quality of the implementation of character education in informal education institutions (Hidayati, Zaim, Rukun \& Darmansyah, 2014). The claim is based on social phenomena that develop as described previously. Therefore, formal education institutions as an official forum for coaching young people are expected to increase their role in shaping the personality of students by increasing the intensity and quality of character education.

The background of school culture in excellent elementary schools is based on the current condition of society that experiencing moral degradation. In line with this, community feels that there is an inappropriate output from the expected educational output. This imbalance can be seen from the behavior of graduates of formal education which is so clearly felt by the community that is not in line with the aims of noble education such as corruption, promiscuity, drug abuse, and student brawl (Agung, 2011). This school has the intention to preach even though it is in a modern era, by not eliminating the identity of the Indonesian people who have good morals. These character schools always make innovations in developing school culture so that the vision and mission of the school are realized through comparative studies to other schools, through experiences from developed schools, then adopted and used as a model of school culture development. After that, filtered or matched with the environment or condition in elementary school.

The management strategy of school culture for those character schools as recommended by the Ministry of National Education runs through four things; routine school activities/habituation, spontaneous activity/spontaneous habituation, model/model habituation, and conditioning (Wiyani, 2013). First, from the routine school activities, this excellent elementary school has struggled to develop school culture through daily activities or routine activities that are always carried out by students, both through direct and indirect learning, of course, with the right method in line with the curriculum developed (Irawati, Iswahyuni, \& Setyawati, 2019). Second, spontaneous activities, these activities are always carried out by teachers in this elementary school when they learn of the bad things that must be corrected at that time. If the teacher is aware of the bad behavior and attitude, the teacher makes corrections directly so students will not do such things. In order to have effective outcomes from moral and character education, education and reprimand by teachers becomes very important (Campbell, 2008; Fenstermacher, Osguthorpe \& Sanger, 2009; Yiğit \& Tarman, 2013). 
Third, the modeling activity, the headmaster always reminds the school members and good educators who become a role model for the students. Students will imitate what they have seen every day. The above explanation is in line with Arthur that students expect their teachers to involve in the development of character and educational values, the implicit and explicit attention to any values in school. Hence, learners of all ages believe that teachers can make a difference in contributing to the development of their personal moral. According to students in this research, the values of success depend on the teachers' education program as a model and mentor, as well as educators (Arthur, 2011).

Fourth, controlling, as an effort that is always carried out by this excellent elementary school. When there are activities that reflect school culture begin to weaken, all components need to refresh and evoke the enthusiasm. The culture is always cultivate good things in this excellent elementary school. Refreshing and reawakening is the main thing in establishing and strengthening the school culture that has been embedded. Strengthening cultural school aims to grow the character of students themselves. This is supported by Full Day School System, schools with full learning activities also have sufficient opportunities to instill character values and prevent students from activities that are not good. There are three main focuses on character education. First, character education focuses on teaching values. Second, focus on clarifying values. Third, it focuses on moral development (Agung, 2011).

Basically, the management of school culture development is based on its implementation strategy and that takes a long time (Pala, 2011). The implementation of praiseworthy character-based school culture is organized and implemented in the school environment by using modeling, teaching and reinforcing environments (Hartono, Haryanto, \& Asrowi, 2018); (Daryanto \& Darmiatun, 2013). Thus, character becomes the culmination of habits resulting from ethical choices, behaviors, and attitudes possessed by moral individuals even when no one sees (Skaggs \& Bodenhorn, 2006).

Learning models that are relevant to the inductive approach are constructivist learning models, such as DL or Discovery Learning; PBL or Problem Based Learning; and PJBL or Project Based Learning (Oguz-Unver \& Arabacioglu, 2014). They are relevant to character education in the context of the 2013 curriculum which uses a scientific approach. With these models, students will find and understand values as the basis for taking certain moral attitudes and actions through the process of internalization, namely the developmental change from externally controlled behavior to internal behavior.

Cultivation and inculcation of this character continuously require the process of modelling, teaching, and strengthening the environment of good character. When all school 
components are involved in this culture and inculcation of character, it means that the values, norms, habits of character that have been prioritized must be modeled by all school components (headmaster, teachers, students, and employees), and integrated by each teacher into subjects, and strengthened by structuring the school environment (Daryanto, et all, 2013).

This excellent elementary school carries out modeling, teaching, and strengthening the environment. In the modeling process, the teachers are asked to always be a role model for students. In the teaching process, the 2013 curriculum has provided an implementation of character education through the PPK program (Suherman, Supriyadi, \& Cukarso, 2019). Thus, teachers always integrate character education into the learning process. In planning the learning stage, , attention needs to be paid to class management, organizing teaching materials, managing teaching and learning activities, the use of learning resources, and assessment. Assessment of learning activities can be done by written the examinations, or through direct observation by educators. Character values were chosen that are tailored to the instrument of learning. Also, the chosen character values are adjusted to the characteristics of students and the competencies to be achieved (Khoury, 2017).

In the process of strengthening the environment, excellent elementary school has made efforts by creating and implementing a good school culture in building the student's character. Management of school culture in building the student's character, headmaster, vice headmasters, and the coordinators of the divisions along with the teachers and all components of the school always strive to manage positive school culture. School culture is always developed in building Islamic student's character and always refers to 18 characters, i.e. religious, honest, tolerant, disciplined, hard-working, creative, independent, democratic, curious, nationalist, motherland allegiant, respectful, communicative, loving peace, loving read, care of the environment, care of the social, and responsible (Dirjen Dikdasmen Kemendiknas, 2010).

\section{CONCLUSION}

From the above explanation and discussion, it can be concluded that the management of school culture development in this excellent elementary schools has several stages, i.e. planning, organizing, implementing, and evaluating. In this management of the development of school culture, the headmaster, vice headmaster, and the coordinators along with the teachers and all components of the school always strive to manage school culture that is positive, Islamic-based, and relies on 18 characters; religious, honest, tolerant, disciplined, hard-working, creative, independent, democratic, curious, nationalist, motherland allegiant, respectful, communicative, loving peace, loving read, care of the environment, care of the 
social, and responsible. The strategies for developing school culture in character schools are carried out through routine activities/routine habituation, spontaneous activity/spontaneous habituation, model/model habituation, and conditioning. The implementation of school culture based on the praiseworthy character is organized and implemented in the school environment by using modeling, teaching and reinforcing environments. This finding implies that school culture play a strong role in student character education. Therefore, all school academics must strive and collaborate in creating a good school culture.

\section{REFERENCES}

Agboola, A., \& Tsai, K. C. (2012). Bring character education into classroom. European Journal of Education Research, 1(2), 163-170.

Agung, L. (2011). Character education integration in social studies learning. HISTORIA: International Journal of History Education, 12(2), 392-403.

Amini, A. A., Yurnita, S. Y., \& Hasnidar, H. H. (2017). The development of character education model trough an integrated curriculum at elementary education level in Medan City. IJLRES - International Journal on Language, Research and Education Studies, 1(2), 298 - 311.

Andang. (2014). Manajemen \& kepemimpinan kepala sekolah. Yogyakarta: Ar-Ruzz Media.

Arikunto, A. (2006). Prosedur penelitian suatu pendekatan praktik. Jakarta: Rineka Cipta.

Arthur, J. (2011). Personal character and tomorrow's citizens: Student expectations of their teachers. International Journal of Educational Research, 50(3), 184-189.

Ash-shidiqqi, E. A. (2018). The analysis of character education in Indonesia. International Journal of Humanities, Art and Social Studies, 3(4), 39-46.

Benninga, J. S., Berkowitz, M. W., Kuehn, P., \& Smith, K. (2003). The relationship of character education implementation and academic achievement in elementary schools. Journal of research in character education, 1(1), 19-32.

Billig, S. H., Jesse, D., \& Grimley, M. (2008). Using service learning to promote character education in a large urban district. Journal of Research in Character Education, 6(1), 21-34.

Campbell, E. (2008). The ethics of teaching as a moral profession. Curriculum Inquiry, 38 (4), 357-385. doi: 10.1111/j.1467-873X.2008.00414.X

Daryanto \& Darmiatun, S. (2013). Implementasi pendidikan karakter di sekolah. Yogyakarta: Gava Media.

Deal, T. E., \& Peterson, K. D. (2016). Shaping school culture. John Wiley \& Sons.

Dirjen Dikdasmen Kemendiknas. (2010). Pembinaan pendidikan karakter di Sekolah Menengah Pertama. Jakarta: Dirjen Dikdasmen Kemendiknas.

Fauzia, R. R. (2015). Pembentukan Karakter Siswa Melalui Budaya Sekolah di Sekolah Dasar Islam Terpadu (SDIT) Ya Bunayya Pujon Malang. Skripsi: Universitas Islam Negeri Maulana Malik Ibrahim

Fenstermacher, G. D., Osguthorpe, R. D. \& Sanger, M. (2009). Teaching Morally and Teaching Morality. Teacher Education Quarterly, 36 (3), 7-19 
Fink, E., \& Resnick, L. B. (2001). Developing principals as instructional leaders. Phi Delta Kappan, 82(8), 598-610.

Godfrey, D. (2016). Leadership of schools as research-led organisations in the English educational environment: Cultivating a research-engaged school culture. Educational Management Administration \& Leadership, 44(2), 301-321.

Hackman, J., \& Wageman, R. (2007) Asking the right questions about leadership. American Psychologist, 62(1), 43-47.

Hallinger, P., \& Heck, R. H. (1998). Exploring the principal's contribution to school effectiveness: 1980-1995. School Effectiveness and School Improvement, 9(2), 157191.

Harahap, M. T., Hasyimsyah, H. H., \& Suwardi, S. S. (2017). Communication ethics Ibn Miskawaih and its relevance to the solving of moral problems in Indonesia. International Journal on Language, Research and Education Studies, 1(1), 119-129.

Hartono, Y., Haryanto, S., \& Asrowi, A. (2018). Character education in the perspective of humanistic theory: A case study in Indonesia. EDUCARE: International Journal for Educational Studies, 10(2), 95-107.

Hidayati, A., Zaim, M., Rukun, K., \& Darmansyah, D. (2014). The development of character education curriculum for elementary students in West Sumatera. International Journal of Education and Research, 2(6), 189-198.

Hidayatullah, F. (2010). Pendidikan Karakter: Membangun Peradaban Bangsa. Surakarta: Yuma Pustaka.

Irawatie, A., Iswahyuni, I., \& Setyawati, M. E. (2019). Education learning development of character education-based state defense. International Journal of Multicultural and Multireligious Understanding, 6(8), 27-42.

Khoury, R. (2017). Character education as a bridge from elementary to middle school: A case study of effective practices and processes. International Journal of Teacher Leadership, 8(2), 49-67.

Kurniawan, A. P., Anam, A. C., Abdussakir, \& Rofiki, I. (2019). Integrasi etnomatematika dengan model pembelajaran probing-prompting untuk melatih komunikasi matematis siswa. MaPan: Jurnal Matematika dan Pembelajaran, 7(1), 1-15. https://doi.org/10.24252/mapan.2019v7n1a1

Lewin, K. (1951). Field theory in sosial science. New York: Harper \& Row.

MacNeil, A. J., Prater, D. L., \& Busch, S. (2009). The effects of school culture and climate on student achievement. International Journal of leadership in Education, 12(1), 73-84.

Mahbubi. (2012). Pendidikan karakter implementasi aswaja sebagai nilai pendidikan karakter. Yogyakarta: Pustaka Ilmu.

Mirshekari, A., \& Ghasemi, R. (2019). The study of justice in determining women's rights in the family according to the islamic legal system. Journal of Shariah Law Research, 4(2), 201-222.

Nurhayati, T. (2018). Optimalisasi karakter positif calon guru MI melalui lesson plan berbasis ARCS pada mahasiswa Microteaching PGMI IAIN Syekh Nurjati Cirebon. Al Ibtida: Jurnal Pendidikan Guru MI, 5(1), 11-24.

Oguz-Unver, A., \& Arabacioglu, S. (2014). A comparison of inquiry-based learning (IBL), 
problem-based learning (PBL) and project-based learning (PJBL) in science education. Academia Journal of Educational Research, 2(7), 120-128.

Pala, A. (2011). The need for character education. International Journal of Social Sciences and Humanity Studies, 3(2), 23-32.

Pattaro, C. (2016). Character education: Themes and researches. An academic literature review. Italian Journal of Sociology of Education, 8(1), 6-30. doi: 10.14658/pupjijse-2016-1-2

Redding, S., \& Corbett, J. (2018). Shifting School Culture to Spark Rapid Improvement: A Quick Start Guide for Principals and Their Teams. The Center on School Turnaround Four Domains Series. Center on School Turnaround at WestEd.

Saidek, A. R., \& Islami, R. (2016). Character issues: Reality character problems and solutions through education in Indonesia. Journal of Education and Practice, 7(17), 158-165.

Samong, F., Suryadi, A., \& Budimansyah, D. (2016, April). The development of character education in primary schools through the enhancement of school culture. In 1st UPI International Conference on Sociology Education. Atlantis Press.

Shumer, R., Lam, C. \& Laabs, B. (2012). Ensuring good character and civic education: Connecting through service learning. Asia Pacific Journal of Education, 32(4), 430440.

Skaggs, G., \& Bodenhorn, N. (2006). Relationships between implementing character education, student behavior, and student achievement. Journal of Advanced Academics, 18(1), 82-114.

Sobri, A. Y. (2010). Menumbuhkan nilai karakter siswa di sekolah. Malang: Administrasi FIP.

Stott, K., \& Jackson, A. (2005). Using Service learning to achieve middle school comprehensive guidance program goals. Professional School Counseling, 9(2), 156159.

Sugiyono. (2013). Metode penelitian kuantitatif, kualitatif, dan R\&D. Bandung: Alfabeta.

Suherman, A., Supriyadi, T., \& Cukarso, S. H. I. (2019). Strengthening National Character Education through Physical Education: An Action Research in Indonesia. International Journal of Learning, Teaching and Educational Research, 18(11), 125-153.

Sulasmono, P., Ekosiswoyo, R., \& Widodo, J. (2017). The integration of local cultural wisdom values in building the character education of students. International Journal of Education and Research, 5(6), 151-162

Supratiningrum \& Agustini. (2015). Membangun Karakter Siswa Melalui Budaya Sekolah di Sekolah Dasar. Jurnal Pendidikan Karakter, 5(2), 219-228.

Suryani, A. I., Anwar, Hajidin, \& Rofiki, I. (2020). The practicality of mathematics learning module on triangles using GeoGebra. Journal of Physics: Conference Series, 1470(1), 012079. https://doi.org/10.1088/1742-6596/1470/1/012079

Syarifah, H. Korelasi kultur sekolah terhadap pembentukan akhlak siswa di SMP al-Manar Azhari Islamic Boarding School.

Tłuściak-Deliowska, A., Dernowska, U., \& Gruenert, S. (2017). How School Achievements Interplay with School Culture and Principal Behaviors: A Comparative Study. International Journal of Psycho-Educational Sciences, 10-22. 
Uliana, P. (2013). Implementasi pendidikan karakter melalui kultur sekolah pada siswa kelas XI di SMA Negeri 1 Gedangan Sidoarjo. Kajian Moral dan Kewarganegaraan, 1(1), 165-179.

Wardani, K. (2014). Implementasi Pendidikan Karakter Melalui Budaya Sekolah Di SD Negeri Taji Prambanan Klaten. In Seminar Nasional "Konservasi dan Peningkatan Kualitas Pendidikan di Indonesia", 22 Maret 2014, Universitas Negeri Semarang.

Watson, N. (2001). Promising practices: What does it really take to make a difference?. Education Canada, 40(4), 4-6.

Wiyani, N. A. (2013). Membumikan pendidikan karakter di SD. Jogjakarta: Ar-Ruzz Media.

Yiğit, M. F., \& Tarman, B. (2013). The place and importance of values education in 4.th and 5th. grade primary school social studies textbooks. Journal of Social Studies Education Research, 4(2), 79-102.

Zamroni. (2007). Pendidikan karakter: Strategi mendidik anak di zaman modern. Jakarta: Grasindo.

Zamroni. (2016). Kultur sekolah. Yogyakarta: Gavin Kalam Utama. 